\title{
A participação da sociedade civil nas decisões das agências reguladoras: mitos e desafios
}

Felipe Dutra Asensi*

\section{Introdução}

O direito administrativo está se transformando no Brasil. Os estudos dos "novos administrativistas" brasileiros, tais como Guerra1 (2004a, 2004b, 2005) e Aragão (2002, 2006, 2008), têm evidenciado novos temas, questões e desafios que se apresentam a esse ramo do direito, sobretudo a partir da análise das mudanças institucionais, legais e filosóficas que tem passado ao longo dos últimos 20 anos.

De fato, a tarefa de listar tais transformações é inviável, uma vez que as estruturas e lógicas inerentes ao direito administrativo no Brasil são multifacetadas. ${ }^{2}$ Do ponto de vista da estrutura da administração pública, observase uma inspiração fortemente europeia, principalmente de natureza francesa, que rege a organização da administração, os princípios inerentes às suas ati-

\footnotetext{
* Advogado formado pela Universidade Federal Fluminense (UFF). Cientista social formado pela Universidade do Estado do Rio de Janeiro (Uerj). Pesquisador do Laboratório de Pesquisas sobre Práticas de Integralidade em Saúde (Lappis/Uerj), da Escola de Direito da Fundação Getulio Vargas (FGV) e da Ordem dos Advogados do Brasil (OAB/RJ). Mestre e doutorando em sociologia pelo Instituto Universitário de Pesquisas do Rio de Janeiro (Iuperj). E-mail: <felipedml@yahoo. com.br>.

${ }^{1}$ Agradeço ao Sérgio Guerra, por despertar essa postura analítica de investigação das transformações do direito administrativo em nossos encontros na FGV. Além disso, agradeço pelas críticas e sugestões que realizou.

2 Para uma análise das transformações contemporâneas do direito administrativo brasileiro, ver Baptista (2003), Guerra (2005) e Aragão e Marques Neto (2008). No tocante ao participacionismo nas agências reguladoras, ver Mastrangelo (2005).
} 
vidades e a relação entre cidadão e Estado. Do ponto de vista da lógica de funcionamento, observa-se uma inspiração norte-americana, que considera os espaços de diálogo constituídos no interior da administração, as formas de se estabelecer estratégias de ação com caráter primariamente técnico e a relação entre a administração pública direta e outras formas institucionais de administração estatal, tais como as agências reguladoras.

O cenário do direito administrativo contemporâneo, então, é caracterizado por uma alta complexidade no que concerne à estrutura e à lógica de ação da administração pública. Diariamente, juízes, promotores, advogados, defensores e cidadãos se deparam com questões administrativas. $O$ juiz costumeiramente se depara com os limites e possibilidades de controle dos atos das agências reguladoras. Os promotores estão a todo o momento se debruçando sobre os desafios próprios da ação de improbidade administrativa e da ação de responsabilidade. Os advogados têm buscado constituir algum padrão decisório em relação às transformações atuais, seja por meio de pareceres, seja defendendo seus clientes num contexto litigioso. Os cidadãos, por fim, encontram-se amplamente inseridos nesse contexto de mudança, além de se apresentarem como atores essenciais no âmbito da atividade administrativa.

No Brasil, tradicionalmente, uma das principais características das decisões estatais do ponto de vista legal - sejam elas políticas ou técnicas - é a desnecessidade de participação de tais cidadãos. Inclusive, no direito administrativo, sobretudo com a consolidação do "princípio da supremacia do interesse público", o cidadão se constituiu como "parte fraca" em sua relação com o Estado.

Alguns estudos realizados por juristas e por sociólogos ao longo da história brasileira evidenciam a "fraqueza" do cidadão perante a administração pública. Em nossa formação política, o Estado se constituiu como o locus de movimento e a sociedade o locus da passividade. A análise de Justiniano José da Rocha a respeito do período de reação (momento posterior à ação e anterior à transação), por exemplo, aponta alguns fatores relevantes. Segundo o autor, a influência da localidade nos rumos do país desapareceu no Império: "tudo partiu do governo, tudo ao governo se ligou, o governo foi tudo, e tanto que hoje não há brasileiro que mil vezes por dia não manifeste a convicção de que a sociedade está inerte e morta, de que só o governo vive" (Rocha, 1956:212).

De fato, foi nos momentos em que mais o Estado interveio que a sociedade mais se movimentou, não porque houve um processo social endógeno de mobilização, mas sim porque o movimento foi desencadeado a partir do próprio Estado ou tendo como referencial o Estado. Euclides da Cunha, em certo sentido, traz o relato dessa mobilização a partir do Estado ao analisar a chegada da família real ao Brasil, pois esta teria possibilitado que, pelos mais diversos pontos do país, se irradiasse "a influência governamental com uma intensidade que nunca mais se desenvolveu em toda a nossa existência" (Cunha, 2006:157). 
Nesse contexto, é amplo o debate sobre a influência do Estado no cotidiano das práticas sociais, seja administrativamente, seja politicamente. A tese de Raymundo Faoro sobre a influência do pensamento político português ganha relevo, pois o autor ressalta que o Estado português que se transplantou para o contexto brasileiro e promoveu uma valorização da figura do rei em detrimento da figura do povo. Isso teria produzido efeitos sociais consideráveis no que concerne ao exercício da cidadania nos séculos seguintes. O argumento gira em torno da constatação de que o "ator da história seria o rei, não o povo, como já insinuava a inteligência europeia, por intermédio da soberania popular nascente e dentro da tese do poder transmitido por Deus através da mediação do povo" (Faoro, 1994:25). Além disso, na medida em que o súdito seria "o membro obediente da monarquia, sem resistência, passivamente obediente" (Faoro, 1994:25), temos a perspectiva de que qualquer incremento na dimensão dos direitos ou na cultura cívica seria realizada a partir do Estado, e não da sociedade. Em outras palavras, a "mudança social" seria operada pela "mudança estatal", pois seria primordialmente pela via do Estado que se desenvolveria a sociedade.

Na perspectiva de José Murilo de Carvalho, a organização político-administrativa que se desenvolveu nos séculos posteriores aponta que "os vários grupos que buscavam em modelos republicanos uma saída para a monarquia acabavam dando ênfase ao Estado, mesmo os que partiam de premissas liberais" (Carvalho, 1998: 96). Essa ênfase levou, posteriormente, ao que o autor denominou "longa tradição estatista" do país. Assim, expressões como "vontade geral", "democracia”, "participação" e "espaços públicos" só fariam sentido se inseridas numa lógica que adotasse o Estado como centro, de modo a desempenhar o papel de principal organizador do exercício da cidadania e dos direitos.

De fato, a inserção dos indivíduos "na política se dava mais pela porta do Estado do que pela afirmação dos direitos do cidadão. Era uma inserção que se chamaria com maior precisão de estadania" (Carvalho, 1998:96-97). O termo "estadania", inaugurado por Carvalho, tem considerável potencial semântico e heurístico desse traço característico da cultura cívica brasileira, que é marcada muito mais pela passividade da sociedade civil do que pela sua forte atuação na efetivação, construção e garantia de direitos. Ao analisar o Estado Novo, Francisco Campos enfatiza a presença dessa perspectiva ao sustentar que "não há hoje um povo que não clame por um César" (Campos, 1940:24), o que denota que, mesmo anos após a Proclamação da República, ainda não havia uma sociedade civil emancipada e efetivamente ativa na construção de direitos. ${ }^{3}$

\footnotetext{
${ }^{3}$ Para uma análise sobre a relação entre cidadania no Brasil e efetivação de direitos, ver Asensi (2007).
} 
No bojo do diagnóstico acerca da relação entre sociedade civil e Estado, temos as mudanças no direito administrativo supracitadas. Entre as diversas mudanças, as agências reguladoras se apresentam como as mais radicais. Primeiramente, tais agências se situam na interface entre Estado e governo e não se submetem à hierarquia funcional, orçamentária e decisória da administração pública clássica. Obviamente, as agências possuem um grau de liberdade decisória para a regulação de serviços jamais vistos no Brasil, o que amplia a ideia de "desconcentração" do poder decisório no âmbito estatal.

Em segundo lugar, o que reforça essa liberdade de decisão das agências é o próprio arcabouço jurídico-normativo presente nas diversas legislações de cada uma delas. Em linhas gerais, algumas características presentes nas agências são centrais para o seu desenvolvimento institucional autônomo, tais como:

mandatos dos diretores não coincidentes com os mandatos do chefe do Poder Executivo que os nomeou;

garantias em relação à demissibilidade ad nutum;

autonomia funcional e financeira que permita se organizar livremente;

impossibilidade de reforma de suas decisões pela administração pública direta; etc.

Em terceiro lugar, as agências reguladoras se distinguem da administração pública também do ponto de vista do conteúdo da decisão. No contexto administrativo clássico, o poder governamental possui a prerrogativa de proferir decisões, sejam elas políticas ou técnicas, desde que submetidas à estrutura hierárquica da administração pública. No contexto regulatório, opera-se uma desconcentração das competências e atribuições, de modo que à administração pública caiba proferir decisões políticas, ao passo que às agências caiba proferir as decisões técnicas.

Em princípio, a desconcentração do poder que se estabelece com as agências reguladoras em relação à administração pública não resolveria a questão da centralidade do Estado no Brasil. Apesar da desconcentração dos centros decisórios e das competências e atribuições que lhes são inerentes, é possível pensar que tal desconcentração não produziria, necessariamente, maior incorporação da sociedade civil nas decisões. Comumente, as agências têm sido criticadas pelo tecnicismo, que seria inacessível ao cidadão comum. Porém, tais agências também estabelecem em suas ações cotidianas mecanismos de incorporação dos cidadãos no processo decisório, o que amplia das possibilidades de democratização das decisões e participação da sociedade civil.

Partindo dessa assertiva, surgem algumas questões importantes acerca da implementação e garantia dos direitos dos cidadãos: quem estipulará a forma pela 
qual as políticas devem ser implementadas? Quais os indivíduos ou instituições legítimas para isso? Quem detém a legitimidade para dizer e avaliar em que medida se deve ampliar a satisfação de um direito? As respostas foram encontradas no próprio seio social, pois somente a sociedade poderia indicar as deficiências e os problemas das ações do Estado, já que é a sociedade que sofre diretamente as suas consequências. A partir daí, ganhou força o discurso de uma terceira dimensão da igualdade, que vai além da "igualdade formal" ou da "igualdade material", que é a "igualdade de participação". E essa participação se desenvolve em espaços públicos abertos a qualquer cidadão. Espaços que não se reduzem ao mero exercício do voto, na medida em que pressupõem uma postura ativa dos cidadãos na formulação, execução e fiscalização de decisões públicas.

Nas agências, a realização de consultas e audiências públicas, a constituição de ouvidorias e a própria incorporação direta das demandas sociais no processo decisório têm evidenciado que a crítica do tecnicismo deve ser contraposta à possibilidade de participação do cidadão comum, de modo a construir conjuntamente as decisões de tais agências. Assim, é possível afirmar que a participação não se reduz à mera representação política, pois adota como pressuposto a ideia de que a democracia não deve se encerrar no voto ou no procedimento eleitoral. A democracia se faz no cotidiano das práticas dos atores sociais; ou seja, a democracia participativa pressupõe a existência de "espaços públicos de participação", nos quais estejam presentes representantes e representados com igualdade de voz e voto.

As agências permitem pensar um cenário em que a democracia deva ser provida de mecanismos de participação contínua dos cidadãos no processo de formulação, promoção e fiscalização dos serviços públicos. Em decorrência disso, a legitimidade das decisões seria constituída na interface entre o órgão regulador autônomo e o cidadão, já que as decisões realizadas nesses espaços públicos contariam com a deliberação daqueles que vivem e conhecem as mazelas e avanços de um serviço público.

Por isso, este artigo se propõe a pensar os fundamentos políticos e jurídicos da participação nas agências reguladoras. Busca, portanto, estabelecer uma abordagem interdisciplinar que discuta os fundamentos da participação no âmbito do Estado, de modo a evidenciar as transformações estruturais e lógicas pelas quais passa o direito administrativo brasileiro e discutir o cenário participativo das agências. No próximo tópico, intitulado “O debate contemporâneo sobre democracia participativa", será realizada uma discussão sobre os pressupostos e princípios inerentes à democracia participativa, com enfoque especial para a ciência política e o direito. Em seguida, no tópico intitulado "Participação e agências reguladoras", será realizada uma análise das legislações fundadoras das diversas agências reguladoras brasileiras, buscando discutir as questões jurídicas que envolvem a participação em tais agências. Por fim, no tópico intitulado "Conclusão: novos 
desafios na regulação" busca-se refletir sobre os desafios que se apresentam ao direito administrativo brasileiro nesse cenário de abertura estatal à sociedade civil, principalmente a partir da incorporação do cidadão no processo decisório da regulação.

\section{O debate contemporâneo sobre democracia participativa}

\section{Democracia representativa e democracia participativa}

Diante do arranjo institucional criado no âmbito das agências reguladoras, que busca incorporar critérios substantivos de participação popular no processo de regulação, suscita-se o debate sobre duas perspectivas acerca da democracia. São perspectivas de democracia que visam justificar "quem" formula as decisões e "por que" as formula ou, mais precisamente, são perspectivas que buscam explicitar como se desenvolvem os mecanismos de poder presentes entre "quem representa" e "quem é representado". Em ampla medida, esse debate nos auxilia na compreensão dos fundamentos da democracia participativa nas agências reguladoras. Vejamos, então, o que chamamos de "democracia representativa" e de "democracia participativa", tomando como ponto de partida a assertiva de Stuart Mill (2003:223):

o único governo que pode satisfazer todas as exigências do Estado social é aquele no qual todo o povo participa; que toda a participação, mesmo na menor das funções públicas, é útil; que a participação deverá ser, em toda parte, tão ampla quanto o permitir o grau geral de desenvolvimento da comunidade; e que não se pode, em última instância, aspirar por nada menor do que a admissão de todos a uma parte do poder soberano do Estado. Mas como, nas comunidades que excedem as proporções de um pequeno vilarejo, é impossível a participação pessoal de todos, a não ser numa parcela muito pequena dos negócios públicos, o tipo ideal de um governo perfeito só pode ser o representativo.

Mill adota o critério populacional para definir a conveniência da democracia representativa, ou seja, diante do aumento do número de indivíduos que compõem uma dada sociedade, somente por meio de representantes seria possível a sua organização política. Primeiramente, deve-se dizer que a ideia de democracia representativa remete à noção de que temos, de um lado, representantes eleitos e, de outro, representados eleitores. O seu conceito está intimamente relacionado ao conceito de cidadania, pois pressupõe que todos os membros de uma comunidade 
- os cidadãos - têm o direito de escolher os destinos de seu país. Em virtude da complexidade das relações modernas e do alargamento do conceito de cidadão a milhares de pessoas, seriam necessárias instâncias de representação da sociedade que decidissem em nome de todo o corpo social. Nessa perspectiva, o problema de institucionalizar práticas democráticas "deve ser pensado nos termos de duas lógicas políticas: a lógica societária, representada pelos movimentos socais e associações voluntárias; e a lógica estatal, representada pela tentativa de institucionalizar a delegação do poder"4 (Avritzer, 2002:35).

Tais lógicas trazem a convivência cotidiana de duas formas de sociabilidade que atuam no campo político: a sociedade e o Estado. Pensar no tema da democracia representativa, portanto, implica refletir sobre os arranjos institucionais criados a partir da relação entre essas duas lógicas. É importante salientar a análise de Pitkin sobre o tema. A autora realiza uma reflexão histórica e semântica do conceito de representação. Segundo seu argumento, a ideia de "representação" tem sua origem na palavra latina representare, que significa "tornar presente ou manifestar; ou apresentar novamente" (Pitkin, 2006:17). Por outro lado, em virtude da complexidade da representação, surgem desafios sobre como "tornar presente o que não está efetivamente presente". Isso constitui um paradoxo (Pitkin, 2006:30):

inerente ao próprio significado da representação: tornar presente de alguma forma o que apesar disso não está literalmente presente. Mas, na teoria política, o paradoxo é recoberto por várias preocupações substantivas: a relação entre os representantes na legislatura, o papel dos partidos políticos, na medida em que os interesses locais e parciais se encaixam no bem nacional, a forma pela qual a deliberação se relaciona com o voto e ambas se relacionam com o exercício do governo etc.

Assim, a ausência do representado é atenuada por meio de mecanismos em que a atuação do representante seja publicizada e, de certa forma, passível de controle, o que não quer dizer que esse controle seja absoluto e que não haja uma margem de autonomia nas ações do representante. Por essa razão, é possível identificar três sentidos no âmbito da democracia representativa:

significa que as decisões devam ser realizadas por representantes cuja legitimidade advém da lei ou do voto, pois, embora o povo não governe, "ele não está confinado ao papel de designar e autorizar os que governam. Como o governo

\footnotetext{
${ }^{4}$ Todas as citações em idioma estrangeiro foram traduzidas pelo autor deste artigo.
} 
representativo se fundamenta em eleições repetidas, o povo tem condições de exercer certa influência sobre as decisões do governo" (Manin, 1995:8);

afasta a ideia de poder absoluto, na medida em que o representante deve agir nos limites impostos pelos representados, desfrutando de relativa margem de autonomia. Por outro lado, isso não quer dizer que o representante deva fazer o que o representado determina. O que possibilita essa relação conflituosa é a liberdade de opinião, que atenua a não vinculação do governante às opiniões do governado, já que a "liberdade de opinião surge, assim, como contrapartida à ausência do direito de instrução" (Manin, 1995:12);

significa uma alternativa à complexidade moderna, em que não há mais espaços para modelos democrático-participativos diretos, a exemplo da polis grega. Assim, "a vontade popular se torna um componente reconhecido do ambiente que cerca uma decisão" (Manin, 1995:12), tendo em vista que a seleção de representantes ocorre por meio de um procedimento eleitoral.

Em contrapartida, podemos observar o debate sobre outra perspectiva de democracia, ancorada na ideia de participação dos então eleitores no processo decisório, passando estes a atuar como atores efetivos no processo de formulação e execução de políticas. Trata-se de uma perspectiva que "relaciona a emergência da democracia política à formação de espaços públicos nos quais os cidadãos podem participar como iguais e, através da discussão sobre projetos coletivos para a sociedade, formular e guiar decisões políticas" (Avritzer, 2002:5).

Podemos dizer que a democracia participativa não se reduz à representação, pois toma como pressuposto essencial a ideia de que a democracia não deve se encerrar no voto ou no processo eleitoral. A democracia se faz no cotidiano das práticas dos atores; ou seja, a democracia participativa pressupõe a existência de "espaços públicos de participação" nos quais estejam presentes representantes e representados com igualdade de voz e voto. Na análise de Cohn (2003), a democracia participativa:

significa o reconhecimento não só da existência de uma tensão crescente entre Estado e sociedade, mas também do fato de que a esfera estatal não se caracteriza mais como sendo o monopólio do espaço de existência da esfera pública. A consequência lógica é a necessidade de que o próprio Estado passe a incorporar de forma ativa a sociedade civil, conferindo espaços próprios às modalidades emergentes de solidariedade social. Isso porque, dado que se o estatal e o público não se confundem, o fortalecimento da sociedade civil tem que se tornar solidário com a construção da democracia e da cidadania, implicando a própria democratização do Estado. É nessa re- 
articulação das relações do Estado com a sociedade civil que passa a residir a possibilidade de emergência das condições para a recriação da cidadania política e expansão da cidadania social.

O tema da relação entre Estado e sociedade civil tem sido explorado por diversos autores, constituindo-se como uma temática instigante no debate do direito e das ciências sociais. Como fio condutor, observa-se um cenário em que democracia deva ser provida de mecanismos de participação contínua da população no processo de formulação, promoção e fiscalização das políticas públicas. Em decorrência disso, sua legitimidade advém do próprio corpo social, já que as decisões realizadas nesses espaços públicos contam com a deliberação daqueles que vivem e conhecem as mazelas e avanços de um serviço público. A discussão no âmbito participativo remete ao mundo da vida em seu aspecto mais cotidiano, concentrando-se os debates políticos “sobre o que fazer (...). Isso é definido pelo seu propósito prático" (Elster, 1997:25). Assim, pensar em termos práticos requer que os participantes estejam inseridos no contexto político, econômico e social em que vivem, emergindo "em continuidade ou animados por uma conexão genuína com o tecido social - ou mundo da vida, como se queira" (Lavalle, Houtzager e Castello, 2006:46). A representação, no contexto participativo, é "identitária e supõe, por mediação da identidade, a abolição da distância entre representado e representante" (Lavalle, Houtzager e Castello, 2006:51).

Nesse ponto, pode-se observar que, em ambas as perspectivas de democracia (representativa e participativa) há esferas representativas, as quais se compõem de representante, representado e locus. Mais precisamente (Lavalle, Houtzager e Castello, 2006:50):

Na elaboração da tipologia, a representação conjuga três elementos: o representado, sempre pessoas cuja vontade se consubstancia de maneira em maior ou menor grau direta e concreta (voto, reclamo, petição), ou de maneira necessariamente indireta e abstrata (nação, tradição, bem comum); o representante, intermediário e guardião dos interesses do representado, cujo papel descansa em graus diversos de institucionalização, de autorização e de obrigatoriedade para com os representados; o locus, a um só tempo instância onde a representação é exercida e interlocutores perante os quais se exerce - notadamente o poder público, mas não só.

Neste caso, em que as figuras da representação política tradicional resultam inadequadas, o representado tende a coincidir com os beneficiários, por vezes delimitados em termos bastante amplos - "excluídos", "pobres", "comunidade", "cidadãos" - ; o representante corresponde à organização civil investida de tal status por autodefinição; e o locus, especificado apenas de 
maneira implícita na maior parte dos argumentos, via de regra se concentra no poder público e, com menor frequência, em outras instâncias e perante outros interlocutores societários.

O que difere, na verdade, é a forma através da qual as decisões são tomadas. Num nível sociológico, a democracia representativa é embasada na lei, cujos pressupostos são advindos da legalidade e da representação. A democracia participativa, por outro lado, é embasada no corpo social, naqueles que vivem o cotidiano das instituições. Seus pressupostos, então, advêm da sociedade e da participação perene. Outra diferença é a seguinte: a democracia representativa é realizada através de uma "representação concentrada", a qual se divide nos poderes Executivo e Legislativo. A democracia participativa é realizada através de uma "representação pulverizada", na medida em que os espaços públicos de participação são inúmeros e heterogêneos e, por esse motivo, são mais capilares e sensíveis às peculiaridades locais. Os representantes na democracia participativa são membros de uma comunidade específica, portanto, conhecem as práticas dos atores envolvidos na política pública de sua localidade. Ademais, na democracia participativa, quem não é representante também tem direito de voz e voto; a representação é uma mera forma de organização e distribuição de tarefas no espaço público. A peculiaridade desse tipo de democracia nos remete a diversos elementos, entre os quais se destacam (Lavalle, 2003:97-98):

primeiro, sua natureza coletiva ou horizontal, isto é, falou-se em "associações autônomas", "associativismo civil", "ancoragem no mundo da vida"; segundo, o caráter legítimo de suas demandas ou propósitos, concebidos em termos de "interesse geral", "problemas provindos do mundo da vida" ou "objetivos não sistêmicos"; terceiro, a adesão e separação livre e espontânea de seus membros, o que remetia à índole não organizacional ou informal da associação ("associativismo voluntário", "espontaneidade social", "inovação social"); quarto, a importância dos processos de comunicação na formação da vontade coletiva e nas estratégias para suscitar a atenção pública ("tematização pública de problemas"); e, por fim, seu papel de mediação entre a sociedade não organizada e os poderes econômico e político.

O cidadão comum que participa em diversos espaços públicos, tais como as agências reguladoras, é conhecedor da realidade específica de efetivação do seu direito porque faz parte dela em seu cotidiano. As suas ações, logo, terão mais eficácia em um nível microssocial, pois, além de ser um membro da sociedade, o 
cidadão comum também é usuário daquele serviço público regulado. São ações complementares em relação às ações de um congressista, por exemplo, e não antagônicas. Com isso, Avritzer destaca que a democracia participativa se caracteriza por quatro elementos:

deliberação e associação: trata-se da formação de "mecanismos de deliberação face a face, livre expressão e associação";

formas alternativas de resolução de conflitos: trata-se da ideia de que os "movimentos sociais e associações voluntárias encaminham assuntos contenciosos introduzindo no nível público práticas alternativas";

fiscalização do poder público: trata-se de uma forma de preservar "um espaço para a complexidade administrativa e, ao mesmo tempo, desafiar o acesso exclusivo de técnicos aos 'fora' de formulação de decisões. 'Públicos participativos' reservam a prerrogativa de monitorar a implementação administrativa de suas decisões";

politizar demandas sociais: trata-se de uma forma de relacionar "suas deliberações com a tentativa de buscar formatos institucionais capazes de encaminhar no nível institucional os assuntos tornados presentes no nível público" (Avritzer, 2002:52).

Com isso, tem sido debatida a legitimidade social e política das decisões num contexto participativo, sobretudo porque, em diversas circunstâncias, os mecanismos participativos se constituem como essenciais para o processo decisório, como é o caso das agências reguladoras.

\section{Legitimidade social e jurídica da participação}

Como restou observado, a democracia participativa é dotada de uma legitimidade que vai além do aspecto formal da lei: a legitimidade social. A participação do cidadão comum representa a manifestação concreta dessa legitimidade no âmbito da regulação.

O Estado, portanto, passa a ser o locus de reivindicações, tendo em vista sua capacidade institucional de garantir direitos. Porém, o Estado "não deve ser contido [nem conter, no sentido impeditivo do termo] pela sociedade civil, mas construído de fato, de sorte a atuar como garantia institucional da pluralidade de formas de vida" (Costa, 1997:16).

De início, é preciso definir um "papel legal" da participação nas agências, que seria a participação na formulação, promoção, fiscalização e regulação dos servi- 
ços públicos. Essa participação pode ser de forma decisória ou de forma deliberativa, dependendo de como se configuram as normas específicas de cada agência. Portanto, é a legislação específica de cada agência que define, delineia e atribui o "papel legal" que os cidadãos comuns terão no processo decisório.

Por outro lado, é possível sustentar a existência de um "papel social" que extrapole a mera previsão normativa. De fato, é o papel social exercido por tais cidadãos que confere força às decisões das agências, de modo a tornar efetiva sua participação na regulação, à medida que a "democratização completa é a capacidade de transformar novas práticas de inovação societária dentro do espaço formal de formulação de decisões" (Avritzer, 2002:5). Trata-se de trazer para o debate estatal temas e concepções sociais. Esse papel social é desempenhado à medida que o cidadão atua como um veiculador de demandas, ou seja, como um ator relevante na pactuação e negociação, para que as demandas sociais dos usuários de serviços públicos sejam legitimamente reconhecidas, construídas e garantidas no interior das agências.

Assim, temos, no âmbito das agências reguladoras, verdadeiros "espaços públicos de participação institucionalizados, não governamentais (apesar de serem estatais), e legitimadores de demandas sociais por intermédio do diálogo", sob a perspectiva de que uma esfera pública local "pode tornar-se o espaço primário para discutir identidades, formar solidariedades e discutir interesses numa base não particularística" (Avritzer, 2002:48).

\section{Elementos políticos da participação}

O que se observa, no âmbito da democracia participativa das agências, é o protagonismo dos cidadãos como atores e sujeitos no processo de regulação dos serviços públicos. Por essa razão, o que caracteriza o espaço público que se constitui nas agências é a sua composição heterogênea e multifacetada, que congrega diferentes histórias de vida e visões de mundo e acaba por transformá-lo num contexto de "alteridade". Essa alteridade produz um arranjo institucional cuja principal estratégia de negociação e pactuação é o diálogo.

Em decorrência desse espaço de alteridade, temos a tentativa de descaracterização do abismo entre o "eu" e o "outro". Na verdade, esse espaço heterogêneo da participação na agência amplia as possibilidades de aceitação das ideias do outro; amplia o reconhecimento de que suas próprias ideias são falíveis e contingentes; e, principalmente, amplia a possibilidade de estranhamento e relativização das próprias concepções. Como desdobramento, a ação pode se desdobrar para além do reconhecimento da alteridade existente entre o "eu" e o "outro", ao buscar enfatizar que somente uma atitude de "nós todos" pode ser efetiva a ponto de superar as 
"nossas" contradições "particulares". A ideia de "eu" e "outro" passa a ser substituída pela ideia de "nós". "Nós" representa a síntese de um processo dialético, amorfo, heterogêneo, conflitivo, no qual "eu" e "outro" disputam a prevalência de suas convicções. Na maioria das vezes, essa síntese é possível somente através de um processo de "concessão recíproca". Por isso (Costa, 1994:43):

A disputa de ideias se dá em torno dos temas que irão, num acirrado processo seletivo, cristalizar-se na forma do que se entende como opinião pública que, nesse caso, é necessariamente diferente da soma de opiniões individuais medidas nas pesquisas de opinião. Ela representa a amalgamação de consensos públicos amplos.

Por isso, o espaço da participação na agência é o espaço do conflito, da pactuação e da negociação, já que pressupõe o embate entre diferentes concepções que devem, por meio do diálogo, chegar a um denominador comum, afastando os particularismos. Esse denominador passa pelo reconhecimento da presença do "outro" e da competência do "outro".

Logicamente, todo mecanismo de participação apresenta deficiências de diversas naturezas. Manin, analisando a formação histórica da democracia representativa, aponta que esta traz em seu bojo a necessidade de transparência e publicização das ações do Estado, de modo que todos se sintam aptos, por meio da informação, a pleitear direitos e exercer a cidadania. Segundo análise do autor, tal tipo de democracia preconiza que os cidadãos, para que "possam formar opinião sobre assuntos políticos, é necessário que tenham acesso à informação política, o que supõe tornar públicas as decisões governamentais" (Manin, 1995:11).

No âmbito da democracia participativa, a importância da informação é ainda maior, na medida em que são pessoas da comunidade que participam das decisões. Por isso, o problema principal para a consolidação da participação social nas agências consiste nas deficiências de formação dos próprios cidadãos. Vejamos um exemplo simples, mas que denota a complexidade da questão. No caso da regulação em saúde suplementar, é possível identificar deficiências de duas naturezas: a) os cidadãos podem não possuir um conhecimento aprofundado da estrutura e do funcionamento da saúde suplementar; b) os cidadãos não necessariamente possuem um conhecimento técnico sobre medicamentos, equipamentos, tecnologias da saúde, nomenclaturas da medicina etc.

Manin, analisando a democracia representativa, observa que a igualdade de vontades foi colocada na base das concepções políticas, de modo que "nenhuma superioridade intrínseca confere a determinados indivíduos o direito de impor sua vontade aos demais" (Manin, 1995:15). Em consequência dessa igualdade, "todos 
os participantes devem procurar conquistar o consentimento dos outros através da persuasão" (Manin, 1995:15). No âmbito da democracia participativa, segundo o autor, se observa o seguinte:

há uma relação de trocas desiguais de informação, tendo em vista que os participantes são desiguais. Diferentemente do cenário representativo clássico, em que a igualdade entre os representantes é fundamental, no cenário participativo a desigualdade é que fundamenta a pluralidade de visões que permitirá um consenso dialógico nas decisões;

diferentemente do cenário representativo, o cenário participativo preconiza que as decisões sejam por meio de consenso e não por persuasão. Não se trata de eleger, entre as diversas possibilidades, uma decisão racionalmente adequada por meio da persuasão, mas de estabelecer, por meio de um processo dialógico, uma decisão consensual que se caracteriza pelo exaustivo debate;

de forma semelhante ao cenário representativo, o cenário participativo permite que as decisões sejam tomadas durante as discussões em diversos espaços, predominando a ideia de alteridade em suas discussões. No cenário representativo, o que diferencia é que as decisões são tomadas no Parlamento e não em outros espaços públicos de participação.

Mais precisamente, um dos principais desafios da democracia contemporânea consiste no fato de os eleitores parecerem "responder" ("aos termos específicos que os políticos propõem em cada eleição"), mais do que "expressar" ("suas identidades sociais ou culturais"), o que denota que "a situação atual representa um afastamento do processo de formação de preferências políticas na democracia de partido. Hoje em dia, predomina a dimensão reativa do voto" (Manin, 1995:27). Nessa linha, diante da insuficiente formação e do desconhecimento da população, o espaço participativo pode se tornar um mero legitimador dos projetos estatais. A preocupação consiste, então, no movimento de tornar a agência num verdadeiro e efetivo espaço "público" de participação no qual todos devem ter condições de participar em virtude da sua "formação adequada" e "da consciência do papel participativo".

Na verdade, a atuação participativa nas agências tem se mostrado cada vez mais efetiva e reconhecida na sociedade, sobretudo em virtude de seu arcabouço jurídico-institucional. Porém, se trata de um arcabouço que foi constituído, em muitos casos, em momentos posteriores à fundação das agências, pois não se encontram previstos nas leis que as originaram. Surge, então, o debate sobre o participacionismo nas agências, principalmente porque as instâncias participativas presentes nas leis, em muitos casos, não se caracterizam como instâncias decisórias. 


\section{Participação e agências reguladoras}

\section{A previsão legal da participação}

No Brasil, o participacionismo recebeu destaque no período constituinte. A Constituição de 1988 é fruto de exaustivos debates entre diversos atores sociais e políticos. Ela representa o resultado de lutas de mais de 20 anos, que culminam na garantia de direitos individuais, sociais e coletivos, e na universalização de alguns direitos como atributos de cidadania e, simultaneamente, dever do Estado brasileiro.

Com isso, o arcabouço jurídico-institucional que se estabeleceu com a Constituição enfatizou a relação de aproximação entre sociedade civil e Estado, de modo a incorporar caracteres substantivos de cidadania no processo decisório. Inclusive, tal aproximação recebeu forte destaque no próprio fundamento do poder na República brasileira, configurando-se como princípio constitucional basilar. O parágrafo único do art. $1^{\circ}$ estabelece que "Todo o poder emana do povo, que o exerce por meio de representantes eleitos ou diretamente, nos termos desta Constituição".${ }^{5} \mathrm{O}$ povo, portanto, passa a ser o fundamento do poder estatal e, simultaneamente, seu referencial de atuação.

Para além dessa dimensão filosófico-política da participação presente na Constituição, é possível observar uma série de dispositivos constitucionais que reforçam o participacionismo no Brasil. Lock (2004:124-125), em análise minuciosa sobre a participação na administração pública, realizou uma enumeração dos dispositivos constitucionais em que esta se desenvolve. Segundo o autor:

$\mathrm{O}$ art. 5o (Dos direitos e garantias fundamentais), no inciso XIV, assegura a todos o acesso à informação; nos incisos XXXIII e XXXIV, garante o direito de receber informações dos órgãos públicos e o direito de petição, materializando o princípio da publicidade; garante também nos incisos LV e LXIX, o devido processo legal administrativo e o mandado de segurança contra ilegalidade ou abuso de poder de autoridade pública; no inciso LXXIII, garante ainda o controle da conduta dos agentes públicos pelo cidadão através da ação popular, e para completar, no $§ 2^{\circ}$ do mesmo artigo, afirma que além dessas garantias, não se exclui nenhuma outra decorrente dos princípios adotados pela Carta, ou dos tratados internacionais em que o país seja parte, abrindo-se, portanto, uma infinidade de oportunidades de participação na administração pública. No art. 10, assegura a participação dos trabalhado-

\footnotetext{
${ }^{5}$ Brasil, 1999:15.
} 
res e empregadores nos colegiados dos órgãos públicos em que seus interesses profissionais ou previdenciários sejam objeto de discussão. No art. 14, assegura a idéia da soberania popular e o voto direto e secreto de igual valor para todos, prevendo ainda o plebiscito, o referendo e a iniciativa popular, instrumentos importantes da democracia participativa. No âmbito municipal, o art. 29, XII, garante participação no planejamento e o art. 31, $\S 3$, garante a ampla fiscalização das contas. Ao disciplinar os princípios que regem a administração pública o art. 37, §3ํㅡㄹ possibilita ainda a criação de outras formas de participação do usuário na administração pública. Há também a possibilidade da participação popular no processo legislativo, através de audiências públicas e reclamações contra atos das autoridades, nas comissões das casas legislativas, previstas no art. 58, II e IV, bem como a participação diretamente na produção de leis, através da iniciativa popular prevista no art. 61, §2ㅇ. Possibilitando a atuação do cidadão enquanto fiscalizador da conduta do administrador, prevê o art. 74, §2-, a possibilidade de denunciar irregularidades ou ilegalidades ao Tribunal de Contas da União. Prevê ainda a participação de cidadãos no Conselho da República, conforme disposto no art. 89, VII, e a participação de entidades de representação de classe na escolha do quinto constitucional para integrantes dos Tribunais Regionais Federais, Tribunais Estaduais e do Distrito Federal, conforme disciplinado no art. 94. Disciplina também a participação popular na gestão da atividade de administrar, tais como: dos produtores e trabalhadores rurais no planejamento da política agrícola (art. 187); dos trabalhadores, empregadores e aposentados nas iniciativas relacionadas à seguridade social (art. 194, VII); da comunidade em relação às ações e serviços de saúde (art. 198, III); da população através de organizações representativas nas questões relacionadas à Assistência Social (art. 204, II); a gestão democrática do ensino público (art. 206, VI); da colaboração da comunidade na proteção do patrimônio cultural (art. 216, §1으); da coletividade na defesa e preservação do meio ambiente (art. 225); de entidades não governamentais na proteção assistencial integral à saúde da criança e do adolescente (art. 227, §1 ${ }^{\circ}$ ) e das comunidades indígenas, inclusive nos lucros, das atividades que aproveitem os recursos hídricos e minerais das suas terras (art. 231, §3ํㅜ).

No período constituinte, observa-se que a temática da participação foi estabelecida e consagrada em diversos dispositivos constitucionais. Isso possibilitou o debate e a definição dos arranjos institucionais que seriam desenvolvidos nos anos posteriores para ampliar os canais de participação da sociedade civil no Estado e, 
mais especificamente, na administração pública. No campo regulatório de serviços públicos recém-desestatizados, observa-se a constituição de instrumentos de controle social como forma de legitimação das decisões das agências reguladoras, de modo a "resguardar os princípios inerentes à prestação estatal (outorgada à iniciativa privada) de interesse público e, conseqüentemente, os direitos fundamentais do usuário" (Lehfeld, 2007:2).

De fato, o fenômeno das privatizações que se desenvolveu na década de 1990 no Brasil, associado ao surgimento de uma série de instituições que passariam a atuar no campo regulatório de diversos setores, permitiu a ampliação da necessidade de legitimação democrática das decisões. Em virtude da inexistência do seu vínculo institucional aos princípios do sufrágio universal, uma agência carece de déficit democrático reflexo, na medida em que "o sistema político, em seu todo, configure-se como não democrático. Isso não impede, no entanto, que a Agência independente seja um instrumento de ampliação da condição democrática do Estado" (Justen Filho, 2003:8).

Assim, na análise de Justen Filho, toda decisão estatal, seja de natureza técnica ou política, envolve uma margem de autonomia decisória. O próprio conceito de regulação econômica incorpora essa opção governamental por uma entre diferentes alternativas, principalmente alternativas participativas. A construção de tais agências também deriva, entre outros motivos, "da ineficiência dos canais tradicionais de manifestação da vontade popular - o que inclui, também, a desvinculação fática e jurídica da vontade do governante eleito e do eleitor" (Justen Filho, 2003:19). Com isso, o campo regulatório foi o que mais produziu avanços no âmbito da administração pública, principalmente no que concerne à participação do cidadão no processo decisório.

Além disso, existem esforços tanto por parte do legislador quanto por parte das agências no sentido de incentivar e democratizar o acesso à informação e aos seus procedimentos decisórios, seja através da criação de instrumentos, como as audiências públicas e de consultas públicas.

Entre os diversos instrumentos de participação previstos nas legislações das agências, a audiência pública tem se destacado enquanto estratégia privilegiada de incorporação da sociedade civil. Esse instrumento consiste num processo de participação aberto aos cidadãos, cujo objetivo é a consulta de um determinado assunto, tema ou decisão. Isso permite a aproximação da administração dos principais interessados na formulação de uma decisão no âmbito das agências (sobretudo no que concerne àquelas que atuam na regulação de serviços): a sociedade civil. Na análise de Lock, as audiências públicas constituem-se em instrumento de legitimação das decisões através de um procedimento democrático, "onde constantemente a comunidade teria o direito de se manifestar sobre a melhor forma de administração da coisa pública e poderia controlar as ações dos governantes 
através de prestações de contas" (Lock, 2004:127). Mais precisamente, a audiência pública permite ao cidadão a obtenção de informações e conhecimento das ações da administração pública, "bem como a possibilidade de avaliar a conveniência, a oportunidade e a intensidade de suas ações, na medida em que estará administrando de forma compartilhada" (Lock, 2004:128). Porém, as possibilidades participativas nas agências que foram criadas pelo ordenamento jurídico não se reduzem às audiências públicas, o que revela a pluralidade de instrumentos de participação cidadã no processo decisório da regulação. Em alguns casos, inclusive, a exigência da participação no âmbito das agências se apresenta como requisito de validade da norma a ser emanada, o que revela que a participação da sociedade civil no processo decisório também pode possuir efeitos jurídicos.

Cumpre, então, refletir sobre os instrumentos participativos constituídos nas agências reguladoras brasileiras, bem como sobre o caráter vinculativo das decisões desenvolvidas a partir desses instrumentos, de modo a refletir sobre os limites e possibilidades de participação da sociedade civil no âmbito regulatório. Nesse sentido, será realizada uma reflexão sobre as legislações que originaram as agências, de modo a refletir sobre os mecanismos de participação presentes em seu "nascimento" institucional a partir das seguintes perguntas:

Há previsão de instrumentos participativos na lei originária das agências?

A decisão realizada por meio de tais instrumentos é vinculante ou meramente consultiva?

O instrumento deliberativo possui capacidade de influir efetivamente no processo decisório?

As agências reguladoras, em sua origem, buscaram efetivamente incorporar a sociedade civil no processo decisório para reduzir seu "déficit democrático"?

\section{Participação e legitimidade das decisões nas agências}

O quadro a seguir foi constituído a partir do exame das legislações de todas as agências reguladoras brasileiras até o ano de 2009. Trata-se de um exame das legislações originárias de tais agências, de modo a refletir sobre a questão participativa no processo decisório, o que não quer dizer que, posteriormente, as agências não tenham constituído, por meio de portarias, regulamentos etc., outras instâncias ou órgãos de participação. Porém, o que importa neste artigo é a filosofia originária, ou seja, em que medida as agências foram pensadas para atuarem de forma conjunta com a sociedade civil e quais os efeitos jurídicos dessa participação que foram previstos nas legislações. 


\section{Participação nas agências reguladoras}

\begin{tabular}{|c|c|c|c|c|}
\hline Agência & Lei & Dispositivos & Formas & Vinculação \\
\hline Aneel & $\begin{array}{l}\text { Lei no } \\
9.427 / 96\end{array}$ & $\begin{array}{l}\text { Art. 4, §1‥ O decreto de constituição da Aneel } \\
\text { indicará qual dos diretores da autarquia terá } \\
\text { a incumbência de, na qualidade de ouvidor, } \\
\text { zelar pela qualidade do serviço público de } \\
\text { energia elétrica, receber, apurar e solucionar as } \\
\text { reclamações dos usuários. } \\
\text { §3ㅇ processo decisório que implicar afetação } \\
\text { de direitos dos agentes econômicos do setor } \\
\text { elétrico ou dos consumidores, mediante } \\
\text { iniciativa de projeto de lei ou, quando possível, } \\
\text { por via administrativa, será precedido de } \\
\text { audiência pública convocada pela Aneel. }\end{array}$ & $\begin{array}{l}\text { Ouvidoria/ } \\
\text { audiência } \\
\text { pública }\end{array}$ & Sim \\
\hline Anatel & $\begin{array}{l}\text { Lei no } \\
9.472 / 97\end{array}$ & $\begin{array}{l}\text { Art. 8o, §7o. A Agência terá como órgão máximo o } \\
\text { Conselho Diretor, devendo contar, também, com } \\
\text { um Conselho Consultivo, uma Procuradoria, uma } \\
\text { Corregedoria, uma Biblioteca e uma Ouvidoria, } \\
\text { além das unidades especializadas incumbidas de } \\
\text { diferentes funções. } \\
\text { Art. 33. O Conselho Consultivo é o órgão de } \\
\text { participação institucionalizada da sociedade na } \\
\text { Agência. } \\
\text { Art. 34. O Conselho será integrado por } \\
\text { representantes indicados pelo Senado Federal, } \\
\text { pela Câmara dos Deputados, pelo Poder } \\
\text { Executivo, pelas entidades de classe das } \\
\text { prestadoras de serviços de telecomunicações, } \\
\text { por entidades representativas dos usuários e } \\
\text { por entidades representativas da sociedade, } \\
\text { nos termos do regulamento. } \\
\text { Art. } 42 \text {. As minutas de atos normativos serão } \\
\text { submetidas à consulta pública, formalizada } \\
\text { por publicação no Diário Oficial da União, } \\
\text { devendo as críticas e sugestões merecer exame } \\
\text { e permanecer à disposição do público na } \\
\text { Biblioteca. }\end{array}$ & $\begin{array}{l}\text { Ouvidoria/ } \\
\text { Conselho } \\
\text { Consultivo/ } \\
\text { consulta } \\
\text { pública }\end{array}$ & Não \\
\hline
\end{tabular}




\begin{tabular}{|c|c|c|c|c|}
\hline Agência & Lei & Dispositivos & Formas & Vinculação \\
\hline ANP & $\begin{array}{l}\text { Lei no } \\
9.478 / 97\end{array}$ & $\begin{array}{l}\text { Art. 19. As iniciativas de projetos de lei ou } \\
\text { de alteração de normas administrativas que } \\
\text { impliquem afetação de direito dos agentes } \\
\text { econômicos ou de consumidores e usuários de } \\
\text { bens e serviços da indústria do petróleo serão } \\
\text { precedidas de audiência pública convocada e } \\
\text { dirigida pela ANP. }\end{array}$ & $\begin{array}{l}\text { Audiência } \\
\text { pública }\end{array}$ & Sim \\
\hline \multirow[t]{2}{*}{ Anvisa } & $\begin{array}{l}\text { Lei nº } \\
9.782 / 99\end{array}$ & $\begin{array}{l}\text { Art. 9‥ A Agência será dirigida por uma } \\
\text { Diretoria Colegiada, devendo contar, também, } \\
\text { com um Procurador, um Corregedor e um } \\
\text { Ouvidor, além de unidades especializadas } \\
\text { incumbidas de diferentes funções. }\end{array}$ & $\begin{array}{l}\text { Ouvidoria/ } \\
\text { Conselho } \\
\text { Consultivo }\end{array}$ & Não \\
\hline & & $\begin{array}{l}\text { Parágrafo único. A Agência contará, ainda, } \\
\text { com um Conselho Consultivo, que deverá } \\
\text { ter, no mínimo, representantes da União, dos } \\
\text { Estados, do Distrito Federal, dos Municípios, } \\
\text { dos produtores, dos comerciantes, da } \\
\text { comunidade científica e dos usuários, na forma } \\
\text { do regulamento. }\end{array}$ & & \\
\hline \multirow[t]{2}{*}{ ANS } & $\begin{array}{l}\text { Lei no } \\
9.961 / 00\end{array}$ & $\begin{array}{l}\text { Art. 5o. A ANS será dirigida por uma Diretoria } \\
\text { Colegiada, devendo contar, também, com um } \\
\text { Procurador, um Corregedor e um Ouvidor, } \\
\text { além de unidades especializadas incumbidas de } \\
\text { diferentes funções, de acordo com o regimento } \\
\text { interno. }\end{array}$ & $\begin{array}{l}\text { Ouvidoria/ } \\
\text { Câmara }\end{array}$ & Não \\
\hline & & $\begin{array}{l}\text { Parágrafo único. A ANS contará, ainda, com } \\
\text { a Câmara de Saúde Suplementar, de caráter } \\
\text { permanente e consultivo. }\end{array}$ & & \\
\hline ANA & $\begin{array}{l}\text { Lei no } \\
\text { 9.984/00 }\end{array}$ & Inexiste & Inexiste & Inexiste \\
\hline \multirow[t]{2}{*}{ Antaq } & $\begin{array}{l}\text { Lei no } \\
10.233 / 01\end{array}$ & $\begin{array}{l}\text { Art. 52. A Antt e a Antaq terão Diretorias } \\
\text { atuando em regime de colegiado como órgãos } \\
\text { máximos de suas estruturas organizacionais, as } \\
\text { quais contarão também com um Procurador- } \\
\text { Geral, um Ouvidor e um Corregedor. }\end{array}$ & $\begin{array}{l}\text { Ouvidoria/ } \\
\text { audiência } \\
\text { pública }\end{array}$ & Sim \\
\hline & & $\begin{array}{l}\text { Art. 68. As iniciativas de projetos de lei, } \\
\text { alterações de normas administrativas e decisões } \\
\text { da Diretoria para resolução de pendências que } \\
\text { afetem os direitos de agentes econômicos ou } \\
\text { de usuários de serviços de transporte serão } \\
\text { precedidas de audiência pública. }\end{array}$ & & \\
\hline
\end{tabular}




\begin{tabular}{|c|c|c|c|c|}
\hline Agência & Lei & Dispositivos & Formas & Vinculação \\
\hline \multirow[t]{5}{*}{ Antt } & \multirow[t]{5}{*}{$\begin{array}{l}\text { Lei no } \\
10.233 / 01\end{array}$} & $\begin{array}{l}\text { Art. 25. Cabe à Antt, como atribuições } \\
\text { específicas pertinentes ao Transporte } \\
\text { Ferroviário: }\end{array}$ & \multirow{5}{*}{$\begin{array}{l}\text { Associações } \\
\text { de usuários/ } \\
\text { Ouvidoria/ } \\
\text { audiência } \\
\text { pública }\end{array}$} & \multirow[t]{5}{*}{ Sim } \\
\hline & & $\begin{array}{l}\text { V - regular e coordenar a atuação dos } \\
\text { concessionários, assegurando neutralidade com } \\
\text { relação aos interesses dos usuários, orientando } \\
\text { e disciplinando o tráfego mútuo e o direito } \\
\text { de passagem de trens de passageiros e cargas } \\
\text { e arbitrando as questões não resolvidas pelas } \\
\text { partes. }\end{array}$ & & \\
\hline & & $\begin{array}{l}\text { Parágrafo único. No cumprimento do disposto } \\
\text { no inciso V, a Antt estimulará a formação } \\
\text { de associações de usuários, no âmbito de } \\
\text { cada concessão ferroviária, para a defesa de } \\
\text { interesses relativos aos serviços prestados. }\end{array}$ & & \\
\hline & & $\begin{array}{l}\text { Art. 52. A Antt e a Antaq terão Diretorias } \\
\text { atuando em regime de colegiado como órgãos } \\
\text { máximos de suas estruturas organizacionais, as } \\
\text { quais contarão também com um Procurador- } \\
\text { Geral, um Ouvidor e um Corregedor. }\end{array}$ & & \\
\hline & & $\begin{array}{l}\text { Art. 68. As iniciativas de projetos de lei, } \\
\text { alterações de normas administrativas e decisões } \\
\text { da Diretoria para resolução de pendências que } \\
\text { afetem os direitos de agentes econômicos ou } \\
\text { de usuários de serviços de transporte serão } \\
\text { precedidas de audiência pública. }\end{array}$ & & \\
\hline \multirow[t]{2}{*}{ Ancine } & \multirow[t]{2}{*}{$\begin{array}{l}\text { MP n- } \\
2.228-1 / 01\end{array}$} & $\begin{array}{l}\text { Art. 8‥ A Ancine será dirigida em regime de } \\
\text { colegiado por uma diretoria composta de } \\
\text { um Diretor-Presidente e três Diretores, com } \\
\text { mandatos não coincidentes de quatro anos. }\end{array}$ & \multirow[t]{2}{*}{ Ouvidoria } & \multirow[t]{2}{*}{ Não } \\
\hline & & $\begin{array}{l}\text { §4 Integrarão a estrutura da Ancine uma } \\
\text { Procuradoria-Geral, que a representará em } \\
\text { juízo, uma Ouvidoria-Geral e uma Auditoria. }\end{array}$ & & \\
\hline \multirow[t]{2}{*}{ Anac } & \multirow[t]{2}{*}{$\begin{array}{l}\text { Lei no } \\
11.182 / 05\end{array}$} & $\begin{array}{l}\text { Art. 9o. A Anac terá como órgão de deliberação } \\
\text { máxima a Diretoria, contando, também, com } \\
\text { uma Procuradoria, uma Corregedoria, um } \\
\text { Conselho Consultivo e uma Ouvidoria, além } \\
\text { das unidades especializadas. }\end{array}$ & \multirow[t]{2}{*}{$\begin{array}{l}\text { Ouvidoria/ } \\
\text { Conselho } \\
\text { Consultivo/ } \\
\text { audiência } \\
\text { pública }\end{array}$} & \multirow[t]{2}{*}{ Sim } \\
\hline & & $\begin{array}{l}\text { Art. 27. As iniciativas ou alterações de atos } \\
\text { normativos que afetem direitos de agentes } \\
\text { econômicos, inclusive de trabalhadores do } \\
\text { setor ou de usuários de serviços aéreos, serão } \\
\text { precedidas de audiência pública convocada e } \\
\text { dirigida pela Anac. }\end{array}$ & & \\
\hline
\end{tabular}


O exame da tabela supra permite discutir algumas questões relevantes no que concerne ao cenário da participação no momento embrionário das agências reguladoras brasileiras. A análise das legislações permite supor três elementos. Primeiramente, observa-se que não há uma evolução ou cumulação dos instrumentos de participação, ou seja, os instrumentos presentes nas legislações das primeiras agências não necessariamente foram reproduzidos nas legislações das agências posteriores. Em segundo lugar, não há um padrão de vinculação das decisões, de modo que boa parte dos instrumentos se configuram como meramente deliberativos, sem qualquer conteúdo decisório. Em terceiro lugar, não há um padrão de instrumentos de participação, que varia de acordo com a legislação, a denominação e as atribuições no interior de cada agência.

Com isso, observa-se um contexto de forte heterogeneidade nas legislações originárias de cada uma das agências. O caso mais radical é a legislação originária da Agência Nacional de Águas (ANA), que não prevê a existência de qualquer instrumento participativo, ao passo que em outro caso (Ancine) só se observa a existência da ouvidoria como instrumento de vocalização de demandas. Nas agências, o instrumento participativo mais utilizado é a ouvidoria, que só não esteve presente na legislação de duas delas (ANP e ANA). Porém, a ouvidoria ainda seria um momento bastante embrionário que indica outros caminhos participativos, na medida em que a ouvidoria representa uma forte assimetria entre Estado e sociedade civil. O contexto da ouvidoria não se apresenta como um espaço público a rigor, pois não admite a construção conjunta de decisões, mas apenas a constituição de um canal de reivindicações individuais de usuários de serviços regulados pelas agências. No caso da Aneel, inclusive, a legislação prevê que a ocupação do cargo de ouvidor será realizada por um dos diretores da agência.

Em três agências (Anatel, Anvisa e Anac) observa-se a previsão normativa da existência de um conselho consultivo. Na ANS, o termo utilizado é "câmara de saúde suplementar", mas é possível estabelecer congruências com a ideia de "conselho consultivo". Esse conselho seria responsável por opinar sobre as decisões das agências, porém, sem qualquer vinculação decisória. Assim, a deliberação do conselho seria consultiva, de modo que a decisão dos diretores da agência não estaria condicionada ao que foi deliberado no conselho. Além disso, a composição do conselho é realizada por indicação do Estado e alguns representantes da sociedade civil, sendo fortemente restrita a sua composição. Isso permite afirmar que o conselho consiste muito mais numa representação que se constitui sem voto, mas sim por indicação, do que por participação efetiva da sociedade civil.

$\mathrm{O}$ instrumento que mais se aproxima de uma perspectiva de participação efetiva da sociedade civil é a audiência pública. Prevista em cinco legislações (Aneel, Antaq, ANP, Antt e Anac), a audiência pública se apresenta como elemento essencial para a realização de decisões no âmbito regulatório. Na Anatel, o termo utili- 
zado é "consulta pública", mas é possível estabelecer congruências com a ideia de "audiência pública". As iniciativas ou alterações de atos normativos que afetem direitos de agentes econômicos, inclusive de trabalhadores do setor ou de usuários dos serviços regulados, devem ser precedidas de audiência pública. Nesse sentido, tais decisões possuem como requisito de validade a realização da audiência.

Por outro lado, a legislação é omissa em relação ao caráter vinculante das decisões construídas nas audiências públicas. Admitir que a audiência pública é requisito de validade da decisão não significa que a decisão realizada no interior da audiência seja vinculante para os diretores das agências. Ainda assim, mesmo diante dessa problemática, a relevância jurídica e institucional da audiência pública tem sido reforçada, o que aponta para caminhos de fortalecimento desse instrumento de participação.

Por fim, ainda é relevante destacar um instrumento participativo presente na legislação originária da Antt: as associações de usuários dos serviços regulados. Tratase da possibilidade de sociedade civil, por meio de associações de usuários, influir efetivamente no processo de construção de decisões em matéria de transportes.

Com isso, é possível realizar algumas conclusões significativas acerca da participação da sociedade civil no âmbito das agências reguladoras brasileiras. Primeiramente, as legislações originárias das agências possuem previsões incipientes de participação, o que não quer dizer que normas, portarias e regulamentos posteriores não tenham ampliado os mecanismos de incorporação da sociedade civil. Em segundo lugar, as deliberações desenvolvidas nos diversos instrumentos de participação não são vinculantes do ponto de vista decisório, o que problematiza a ideia de uma construção conjunta de decisões. Isso produz desafios institucionais e jurídicos consideráveis para a consolidação da democracia participativa no âmbito da regulação brasileira e aponta que a estratégia de criação das agências não se orientou, necessariamente, por uma ampliação da participação em virtude de seu déficit democrático.

\section{Conclusão: novos desafios na regulação}

A participação da sociedade civil no âmbito das agências reguladoras nos indica, parafraseando Habermas (1992), que "algo está mudando no horizonte do direito". Como visto, o direito administrativo encontra-se em transformação no Brasil. Novos temas, questões e desafios se apresentam a esse ramo do direito e isso tem provocado mudanças institucionais relevantes na configuração da relação entre Estado e sociedade. No Brasil, a abertura das agências à participação social tem permitido o fortalecimento do cidadão na esfera pública, o que amplia as possibilidades de democratização de suas decisões. 
De fato, as agências possuem um grau de liberdade decisória para a regulação de serviços jamais visto no Brasil, o que amplia a ideia de "desconcentração" do poder decisório no âmbito estatal. Porém, apesar da desconcentração dos centros decisórios e das competências e atribuições que lhes são inerentes, é possível pensar que tal desconcentração não produziria, necessariamente, maior incorporação da sociedade civil nas decisões. Por outro lado, tais agências estabelecem em suas ações cotidianas mecanismos de incorporação dos cidadãos no processo decisório, o que amplia as possibilidades de democratização das decisões e participação da sociedade civil.

As legislações que deram origem às agências evidenciam que o caminho da democracia participativa no setor de regulação encontra-se aberto e, ainda, indefinido. Trata-se de uma concepção de gestão recente no Brasil, o que aponta novos caminhos e desafios a serem superados nos anos que virão, seja politicamente, seja institucionalmente.

Daí surge a necessidade de se constituir uma agenda de discussão sobre os desafios de consolidação da democracia participativa nas agências, tendo como foco as limitações relativas à incorporação da sociedade civil no processo decisório. Algumas pesquisas sobre a temática poderiam auxiliar no aprofundamento dos estudos sobre participação, a exemplo das seguintes:

Os assuntos e discussões são dominados por um grupo de participantes específico ou há uma alta possibilidade de horizontalização em sua relação?

Os debates são "colonizados" por determinados setores ou a construção da pauta de discussão é conjunta?

As agências produziram posteriormente normas e diretrizes de aprofundamento da participação social em suas estruturas?

Os assuntos técnicos discutidos nos espaços públicos de participação efetivamente são acessíveis a todos os participantes?

Portanto, o reconhecimento do diálogo como estratégia privilegiada de resolução de conflitos e de ampliação da participação representa não somente a expansão das possibilidades de atuação dos atores sociais, mas também uma nova forma de sociabilidade, calcada na celeridade e na efetividade do aperfeiçoamento do setor de regulação. Em razão disso, pode-se dizer que o caminho para a democratização das agências ocorre por meio da própria participação dos atores com o objetivo de reduzir as desigualdades sociais. Deve-se, então, eliminar ou ao menos reduzir o paradoxo evidenciado por Macpherson, segundo o qual "não podemos conseguir mais participação democrática sem uma mudança prévia da desigualdade social e sua consciência, mas não podemos conseguir as mudanças da desigualdade social 
e na consciência sem um aumento antes da participação democrática" (Macpherson, 1977:103). O problema esboçado reside justamente no impasse entre desigualdades sociais, de um lado, e consciência participativa, de outro.

Nesse sentido, não basta mais reconhecer o caráter cidadão das agências reguladoras. A efetivação da democracia não se dá mais na forma da lei ou nos limites da legalidade; ela extrapola o mundo jurídico para, no mundo social, adquirir o seu sentido. Assim, o esforço para a participação na regulação remete ao próprio processo de "cidadanização", ou seja, o processo de tornar garantias formais efetivamente exercidas pelos atores sociais em seu cotidiano. Não se trata mais de se "ter" o direito, mas de "exercê-lo". Deve-se fazer com que esse direito seja efetivamente exercido, lutado e implementado não pelo Estado, mas pelos seus próprios titulares.

No Brasil, pelo observado, o arranjo institucional das agências tem possibilitado cada vez mais uma atuação voltada para a esfera pública, mas ainda enfrenta fortes limitações no que concerne aos efeitos jurídicos da participação no processo decisório, que ainda se encontram incipientes. Em outras palavras, é a partir da congruência e da atuação conjunta da sociedade civil e Estado que se configura possível a garantia de um direito mais cidadão, democrático e efetivo. Temos, no Brasil, um campo específico que prima pela participação para que, por meio da ação política, se realize o interesse público.

\section{Referências}

ARAGÃO, A. S. de. Agências reguladoras e evolução do direito administrativo brasileiro. Rio de Janeiro: Forense, 2002.

2006.

. (Org.). O poder normativo das agências reguladoras. Rio de Janeiro: Forense,

. O direito dos serviços públicos. Rio de Janeiro: Forense, 2008.

; MARQUES NETO, F. P. A. (Orgs.). Direito administrativo e seus novos paradigmas. Belo Horizonte: Fórum, 2008.

ASENSI, F. D. Direito garantido é direito exercido? Cidadania e marca da origem no Brasil. In: ENCONTRO NACIONAL DO CONPEDI, 16., 2007. Anais... Belo Horizonte, 2007.

AVRITZER, L. Democracy and the public space in Latin America. Princeton: Princeton University Press, 2002.

BAPTISTA, P. Transformações do direito administrativo. Rio de Janeiro: Renovar, 2003. 
BRASIL. Constituição da República Federativa do Brasil 1988. 12. ed. Brasília: Centro de Documentação e Informação. Coordenação de Publicações, 1999.

CAMPOS, F. O Estado nacional. Rio de Janeiro: José Olympio, 1940.

CARVALHO, J. M. de. Entre a liberdade dos antigos e a dos modernos: a República no Brasil. In: CARVALHO, J. M. de. Pontos e bordados - escritos de história e política. Belo Horizonte: UFMG, 1998.

$\mathrm{COHN}, \mathrm{A}$. Estado e sociedade e as reconfigurações do direito à saúde. Revista Ciência E Saúde Coletiva, v. 8, n. 1, 2003.

COSTA, S. Esfera pública, redescoberta da sociedade civil e movimentos sociais no Brasil: uma abordagem tentativa. Novos Estudos Cebrap, n. 38, 1994.

- Categoria analítica ou passe-partout político-normativo: notas bibliográficas sobre o conceito de sociedade civil. BIB, Rio de Janeiro, n. 43, 1997.

CUNHA, E. da. À margem da história. São Paulo: Martin Claret, 2006.

ELSTER, J. The market and the forum: three varieties of political theory. In: BOHMAN, J.; REGH, W. (Orgs.). Deliberative democracy: essays on reason and politics. Cambridge: MIT Press, 1997.

FAORO, R. Existe um pensamento político brasileiro? São Paulo: Ática, 1994.

GUERRA, S. Controle judicial dos atos regulatórios. Rio de Janeiro: Lumen Juris, 2004a. 2004b.

. Introdução ao direito das agências reguladoras. Rio de Janeiro: Freitas Bastos, . Temas de direito regulatório. Rio de Janeiro: Freitas Bastos, 2005.

HABERMAS, J. The horizon of modernity is shifting. In: HABERMAS, J. Postmetaphysical thinking. Cambridge: MIT Press, 1992.

JUSTEN FILHO, M. Agências reguladoras e democracia: existe um déficit democrático na regulação independente? Revista de Direito Público da Economia - RDPE. Belo Horizonte, v. 2, 2003.

LAVALLE, A. G. Sem pena nem glória: o debate sobre a sociedade civil nos anos 1990. Novos Estudos Cebrap. São Paulo, n. 66, 2003.

; HOUTZAGER, P. P.; CASTELLO, G. Representação política e organizações civis: novas instâncias de mediação e os desafios da legitimidade. Revista Brasileira de Ciências Sociais, v. 21, n. 60, 2006. 
LEHFELD, L. S.; LEPORE, P. E. A participação cidadã e os instrumentos processuais de controle social das agências reguladoras no Brasil. Revista Jurídica Consulex, v. 105, 2007.

LOCK, F. do N. Participação popular no controle da administração pública: um estudo exploratório. Revista Eletrônica de Contabilidade. Santa Maria-RS, v. 1, n. 1, 2004.

MACPHERSON, C. B. A democracia liberal: origens e evolução. Rio de Janeiro: Zahar Editores, 1977.

MANIN, B. As metamorfoses do governo representativo. Revista Brasileira de Ciências Sociais, n. 29, 1995.

MASTRANGELO, C. Agências reguladoras e participação popular. Porto Alegre: Livraria do Advogado, 2005.

MILL, S. Utilitarism on liberty and representative government. In: WEFFORT, F. C. Os clássicos da política. São Paulo: Ática, 2003. v. 2.

PIKIN, H. F. Representação: palavras, instituições e ideias. Revista Lua Nova, v. 57, 2006.

ROCHA, J. J. da. Ação, reação, transação. In: MAGALHÃES JR., R. Três panfletários do Segundo Reinado. São Paulo: Companhia Editora Nacional, 1956. 